\title{
THE GODS OF YUCATÁN FROM A.D. 1560 TO 1980
}

\author{
BRUCE LOVE \\ University of California, Los Angeles
}

Resumen: En este trabajo se presenta una revisión de documentos etnohistóricos y estudios etnográficos (algunos de mi autoría) en busca de las deidades que aparecen en la vida religiosa de los pueblos mayas de Yucatán. Esta revisión introductoria abarca más de cuatro siglos, desde 1560 hasta 1980. Muchos de los dioses del periodo colonial temprano siguen vivos hoy en las comunidades indígenas de la península, mientras que otros han desaparecido completamente. Este artículo rastrea su presencia y su ausencia a lo largo del tiempo y propone que tanto su desaparición como su sobrevivencia reflejan su papel en la sociedad maya. Los dioses patronos de grupos sociales/cívicos han desaparecido, mientras que los dioses agrícolas de la selva y del cielo aún perviven.

Palabras clave: deidades mayas, Yucatán, Periodo Colonial, universo maya.

AвSTRACT: This work presents a review of ethnohistorical writings and ethnographic studies (some by the author) in search of Maya deities as they appear in the religious life of the Maya people of Yucatán. This introductory survey spans more than four centuries, from the 1560s to the 1980s. Many of the gods of the early Colonial Period continue living today in the indigenous communities of the Peninsula, while others have disappeared completely. This article traces their presence or absence over time and proposes that their disappearance or survival is a reflection of their role in Maya society. The patron gods of social/civic groups have disappeared while the agricultural gods of the forest and the sky survive today.

KeYwords: Maya deities, Yucatán, Colonial Period, Maya Universe.

RECEPCIÓN: 13 de agosto del 2010.

ACEPTACIÓN: 5 de octubre del 2010. 



\title{
THE GODS OF YUCATÁN FROM A.D. 1560 TO 1980
}

\author{
BRUCE Love \\ University of California, Los Angeles
}

\section{Introduction}

This article investigates what has happened to the gods of Yucatán over the last half a millennium. At a time when native languages and religions are changing rapidly in the face of globalization—and in the case of Yucatán, Cancunizationanthropologists and linguists are working to record for posterity the belief systems extant across the peninsula; yet even as these ethnographies become available, questions will remain about the intervening years when the gods of the late prehispanic Maya transformed - those that survived at all- to become the spirit beings of today's rites and ceremonies.

This article investigates two periods, from A.D. 1560s to 1650s and from 1850 s to 1980 . Between the two lies fully two centuries from which I found no data for this survey. Of the ethnohistorical sources consulted for this work, the 1560s see the earliest written descriptions of Maya religious practices by Spaniards. The early 1980s is the end date because that was the time I was collecting all ethnographies I could find-in the United States, Mexico City and Yucatánin preparation for writing my doctoral dissertation. Since then, numerous ethnographies and other works based on ethnographic sources have appeared that are not covered by this paper because I have not had access to all the material and, since completing my dissertation, I have not stayed current in this particular field. I proffer to others these last three decades and defer to their expertise the task of summarizing them. ${ }^{1}$

\footnotetext{
${ }^{1}$ There are other limits to this work's coverage that deserve explanation. The Books of Chilam Balam and the Ritual of the Bakabs are excluded from consideration even though they fall within the category of ethnohistorical sources (see Gibson and Glass, 1975: 379-391). They are so rich in religious material, yet so unevenly translated and understood, that to mine them for relevant data would require an immense undertaking worthy of a book-length treatise. Students interested in pursuing god names in the Chilam Balams are encouraged to begin with Barrera Vásquez and Rendón (1948: 81-85; republished with English translations in Kelley 1976: 103-105) and with Roys' glossary of proper names for the Ritual of the Bakabs (1965: 143-161).

Another topic avoided here is syncretism and the place of Catholic saints, the Holy Trinity, Jesus and Mary, and the cross itself within the Maya pantheon of venerable supernatural beings. The subject is so complex and far-ranging that it must await treatment elsewhere. Redfield and Villa Rojas' (1934) careful discussion of the overlap of Christian and "pagan" religious practice remains worthwhile reading today, as does Villa Rojas' ethnography, particularly regarding the cross $(1945 ; 1978)$.
} 
The ethnohistorical sources reviewed here cover the last half of the sixteenth century and the first half of the seventeenth. The ethnographic sources begin in the middle of the nineteenth, leaving two centuries in between without mention. As student of history and culture begin to fill in these centuries with archival research and publications, one hopes for a better understanding of the processes that resulted in the wholesale transformation of many aspects of Maya cosmology; some parts changing dramatically, others dropping out altogether, and yet others persisting to the present day.

\section{Deities vs. spirit beings}

One of the challenges of the present work has been to define the word god as opposed to spirit being or supernatural force. The winds that cause sickness and are the object of modern-day shamans' prayers of exorcism certainly cannot share equal status with the once great Itzamna and K'uk'ulkan, but the winds that bring rain do indeed reach deity status in the ethnohistorical sources as Bakabs of the four world directions. Are the chaaks really gods of thunder and lightning or are they personified natural forces? And what about the forest goblins, the aluxo'ob?

The present work circumnavigates these distinctions by lumping rather than splitting and leaves gods loosely defined as invisible, supernatural forces with wills of their own, forces that are venerated and prayed to and to whom offerings are given in exchange for protection and bounty. Under this definition, the minor winds that cause sickness are not deities (offerings are not left for them, they are swept away in cleansing rites) but the greater winds, the winds of the four directions, do qualify because they are prayed to and they are expected to partake in the offerings laid out for them. The aluxes also qualify because they, too, receive offerings and are expected to help and protect the corn farmers in return.

Deities-and-spirit-beings becomes a catchall rubric which, although perhaps overly broad, does allow the following discussion to proceed apace. A clearer distinction between classes of supernaturals warrants debate; but rather than attempt that exercise here, perhaps the current presentation-more data-oriented than theoretical—can provide useful fodder for such talk. (The reader is encouraged to consult a fine discussion of this topic in Taube, 1992: 7-9.)

\section{Orthographic conventions}

Throughout the following pages, names of deities and spirit beings are quoted from their ethnohistorical and ethnographic sources. Within the quote marks,

And finally, a major work that is not consulted for this chapter is Ferdinand Anders' Das Pantheon der Maya (1963) an apparently thorough treatment of the subject but regrettably inaccessible to nonGerman readers like me. 
spelling and capitalization are maintained from those sources, for example, "PPa PPhol chac" (Lizana, 1893: 5). Italics are used for Spanish and Mayan (and in one case, French); for Spanish words like santo, and for Mayan in modern usage, not quoted from a particular source, for example, alux or aluxo'ob (-o'ob is the plural suffix). Headings for classes of deities appear in anglicized orthography, not using italics, in headline style capitalization, for example, the santo yuum báalamo'ob (holy lord balams) of Yucatán fall under the category Balams. Translations, as in the preceding sentence, are usually set in parentheses and are my own unless otherwise indicated.

\section{Ethnohistorical Sources}

The sources used in this section constitute only the most accessible of the countless ethnohistorical works, the ones compiled and published by previous researchers. The methodology was simple: I read the material and whenever god names appeared I made a note. At the conclusion, I compiled my notes into categories or types and looked for patterns and repetition that might faithfully reflect Maya religious beliefs. The following paragraphs present the results of this survey with final tabulations of numbers of occurrences followed by a brief discussion.

\section{Landa}

In Diego de Landa's accounts (Landa, 1941), the god mentioned most frequently and in the most varied contexts is Itzamna. In a ceremony in the month Wo, a priest calls to and prays to "Kinich Ahau Itzamna" before reading from a holy book of divination (153). Itzamna appears again as one of the three gods of medicine during a ceremony for Ix Chel, goddess of medicine, in the month Sip (155); and a priest invokes his name along with the chaaks in a festival to anoint the steps of a stone mound in the month Mak (162-164). In addition to these ceremonies, he plays an important role in the New Year ceremonies where idols or statues of his personage are placed in temples to avert "calamities" in the coming year. The images, appearing with other gods and figuring prominantly in two of the four repeating New Year or Wayeb rites, are called variously "Itzamna" (145-146), "Itzamna Kauil" (142) and "Kinich Ahau Itzamna" (147).

Following close after Itzamna in frequency of mention by Landa are the chaaks. They are referred to as gods of the corn fields (Landa, 1941: 161), gods of the "grains" (162-164), and one of the protector gods for cacao growers (164). In the New Year, or Wayeb, rites, they appear in quadripartite form as young males

\footnotetext{
N. del E.: en este artículo se ha respetado la ortografía usada por el autor.
} 
(xiib) with colors (yellow, red, white, and black) of the world directions; "Kan Xib Chac," "Chac Xib Chac," "Sac Xib Chac" and "Ek Xib Chac" (137-138).

After Itzamna and the chaaks, come the bakabs. Very close to the chaaks in role and function, the bakabs appear also in quadripartite form in the Wayeb rites, "Kanal Bakab," "Chacal Bakab," "Sacal Bakab" and "Ekel Bakab" (yellow, red, white and black) (Landa, 1941: 138). They serve as "mediators" for owners of hives and honey in the ceremonies during the month Sek (157) and were consulted for prognostics in a festival to renovate a temple in honor of the chaaks (161). Mentioned in three separate contexts, Hobnil is described as one of the bakabs during a ceremony for owners of hives and honey during the month Sek (157), as a mediator for cacao growers in the month Muan (164), and as a bakab during the Wayeb or New Year ceremonies $(137,139,142)$.

Ix Chel is also mentioned by Landa in three separate contexts: an image of her as goddess of medicine was used in a festival celebrated by physicians and sorcerers in the month Sip (Landa, 1941: 154), she was one of four goddesses at the pilgrimage site of Isla Mujeres (9-10), and her statue as goddess of childbirth was placed under the bed during childbirth (129).

Landa mentions Ek Chuah in two separate contexts, as one of the three patron gods of cacao growers (Landa, 1941: 164) and as a god that guards over travelers (107). Balam is also mentioned twice, in both cases within the context of the New Year ceremonies as idols placed in temples to avert calamities: "Ek Balam Chak," (148) and "Ah Buluc Balam" (148).

Like the chaaks and bakabs, akantuns were quadripartite. During carving of idols, in the month Mol, they were placed at the four corners surrounding the carvers (Landa, 1941: 159), and they appear in four directional colors as stone gods (stelae?) at the house of the principal during the Wayeb rites (137).

It is a bit more difficult to distinguish whether K'inich Ajaw should be considered a separate deity, since his name appears conflated with Itzamna in a festival in the month Wo, as mentioned, but the name appears on its own, "Kinich Ahau," as a statue used in the New Year rites, placed in the house of the principal (Landa, 1941: 144).

Numerous other gods and goddesses make brief appearances in Landa's writings but nowhere else in the sources consulted here. Listing these unique examples would be redundant in light of Tozzer's (Landa, 1941) magnificently complete index and syllabus.

\section{Diego Quijada}

From the Diego Quijada papers (Scholes and Adams, 1938), a collection of documents from 1561-1565-just preceding the presumed date of Landa's more famous manuscript — certain gleanings regarding native religion can be pulled. Itzamna appears in one case as the "major idol" of several idols (Vol. 1: 106), 
and elsewhere appears as one of four named idols prayed to for good health and rain for crops. The other three are "Ix Ku," "Ah Bacab," and "Ah Chac" (Vol. 2: 333-334).

"Ixtab" is mentioned as goddess of hanged persons (Vol. 2: 107), "Kakalku" is named as an idol but with no elaboration as to function (Vol. 1: 114), and "Tabay" is called simply "that devil" (Vol. 1: 63).

\section{Cogolludo}

Fray Diego López Cogolludo, in the Seventeenth century, wrote one of the great histories of Yucatán (Cogolludo, 1954), but to this day it remains unedited and unindexed. Persuing the text for data on Maya gods and goddesses is fruitful, but one can only regret what must be missed by rapid scanning. Nevertheless, the tidbits that emerge are tantalizing.

Itzamna again appears as the most often named deity from the most varied contexts, but the greatest idol among all the diversity of idols, according to Cogolludo's sources, was "Kinchahau” who was married to "Ix azal uoh." Their offspring was the famous "Itzamná," inventor of writing (Vol. 1: 352). In another context, "Hun Ytzamná" was said to be the son of "Hunab Ku", the one true god (Vol. 1: 345). At Izamal there was a temple oracle named for him, "Ytzamat Ul" (Vol. 1: 343), and as "father" in the Maya equivalent of the Holy Trinity, his name is given as "Izóna" (Vol. 1: 343).

"Chak" was a giant, the inventor of agriculture who became god of breads (the harvest?), thunder, and lightening (Vol. 1: 353). This description of Chaak is almost verbatim to that given in the Motul Dictionary, compiled in the final quarter of the sixteenth century (Barrera Vásquez, 1980:19a), a source to which Cogolludo must have had access.

The four bakabs, "Zacál Bacáb, Canál Bakab, Chacál Bakab, y Ekel Bakáb” were said to support the sky and also served as gods of the winds (Vol. 1: 352). "Ixchel" invented or discovered (inventó o halló) medicine (Vol. 1: 352). "Kukulcan" was a historical figure, a great war captain, whom became a god, the idol of which was venerated (Vol. 1: 352), and "Echuah" was said to be the equivalent of the Holy Spirit in the Christian trinity (Vol. 1: 352). The devil was named "Xibalba" (Vol. 1: 346).

\section{Relaciones de Yucatán}

From the fourth quarter of the sixteenth century, the Relaciones Histórico-Geográficas (edited by Garza, 1983) present an incomparably rich set of data, a peninsulawide survey of far-ranging fields from geography to social customs. Deities, or names of principal idols, appear in these documents mainly in the role of guard- 
ians or patrons of certain towns, a role succinctly described in Nicholson's nowclassic "Handbook" article.

An important feature of Mesoamerican religion in general was the concept of a special tutelary relationship between a certain deity, the abogado as the Spanish writers usually phrased it, and a particular socio-political group (Nicholson, 1971: 409).

While many of the relaciones tell of ceremonies and rites that include numerous idols, very few actually name the gods that the idols represent. Several that are named refer to the principal idol or abogado of Saki', the Maya name for Valladolid, Yucatán. One relación mentions "Zaqui” or "Zachi” as not only the idol of the town but the name of a cave where the natives worshiped (Relaciones, 1983, Vol. 1: 163). Another names "Cequi," "un ídolo grande" that they had in Valladolid (Vol. 2: 125). Still others reference "Saciual" (Vol. 2: 83), "Aczaquiual" (Vol. 2: 28), "Zacuil” (Vol. 2: 59, 101), and "Zaquigual” (Vol. 2: 185, 257).

At least seven other towns mentioned in the relaciones had the same names as the gods or idols located there. The Campeche idol had on its head a coiled snake, kaan, with a tick, peech' (Relaciones, Vol. 1: 163). Tihotsuc and Chikindzonot shared their names with their idols (Vol. 2: 198), as did Tekom (Vol. 2: 232), Kanpocolche and Chochola (Vol. 2: 321). Tahdziu [Tahdzib?] was named for the idol "Hunpicdzib," said to have been a female figure made of clay (Vol. 1: 389-390).

Cochuah was an entire province whose abogado or patron protector was the god of the same name, said to be the guardian of maize bread. To this idol the natives sacrificed dogs and armadillos and burned copal resin as incense (Relaciones, Vol. 2: 198). "Kinichhaba, Kinichkakmo, Quitahcutz" and "Quitahcoy" were first inhabitants "primeros pobladores," interpreted by Tozzer as "founder gods" (Landa 1941: 173) of Izamal (Vol. 1: 305; compare Vol. 1: 215).

\section{Lizana}

For the gods of Izamal, there is a far richer narrative than found in the relaciones. Fray Bernardo de Lizana, writing in the early years of the seventeenth century, chronicles sixteenth century religious life at the city (Lizana, 1893). Chapter Four-dealing with temple structures, native idols, and religious practices-is sufficiently rich in data, and difficult enough to access, to warrant a complete translation and presentation here.

About idols in this town of Ytzamal that were venerated during the time that this land was conquered.

There are, in this town of Ytzamal, five cuyos, or high mounds, all made of dry stone, with their main part and repairs, that help to hold the stone high, and the entire constructions are not seen today, but the signs and vestiges are evident on one of them if seen at high noon. The old ones have the most celebrated idol that 
was called Ytzamat $u l$, that means the one who receives and possesses the grace, or the dew, or the substance of Heaven: and this idol didn't have any other names, or he wasn't called by any other name because they say that this was a king, a great lord of this earth, that was obeyed by the son of gods: and when they asked him his name or who he was he only said these words: Ytz en caan, Ytz en Muyal, that means I am the dew, or substance of heaven and the clouds.

This king died and they built altars and he was an oracle (one to whom they listen with respect) and later it will be seen how they built another temple and for what purpose. When the idol king lived, the villages consulted him about the things that happened in remote places and he would tell them this and other future things.

To him they used to bring the dead and they say that he would resurrect them and that he healed the sick and so they held him in great veneration with good reason if he truly were the true god that alone can give life to the dead and health to the ill, because it is impossible for a pagan man or a demon to do, but rather this same god that is lord of life and death. Well, they believed this and they didn't know any other god and for this reason they say that he raised from the dead and that he healed.

These Indians built another altar and temple over another mound to their king or false god Ytsmat $u l$ where they put the figure of a hand that served to remind them and they say that there the dead were raised and the sick were healed by touching the hand and this was the one that was in the west, and so it was called and named Kal ul [Kab ul], that means the hand that does works.

And there they offered sacrifices and gave offerings and made pilgrimages from everywhere. For this reason they have built four roads or foot paths to the four winds, that come from the ends of the earth, and went to Tabasco, Guatemala, and Chiapas, that even today one sees parts of these roads, so many people came to

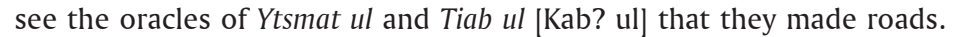

Another mound was made in the north that today is the tallest that is called Kinich KaKmo and it was the cause that over it was a temple and an idol that was called the same and it meant in our language, Sun with a Face, and its rays were the fire and it came down to burn the sacrifice at midday as the Uacamaya was flying down with its feathers of a variety of colors. And this god or idol was venerated and they said that when they had a plague or pestilence or other common illnesses, they would all go to him, the men and the women carrying many presents and they offered them and there in the view of all, the fire would come down, (as it is said), at midday and would burn up the sacrifice. The priest told them what had happened about what they wanted to know about the disease, hunger or plague. In accordance with this they were knowledgeable of good and evil.

There was another cuyo (mound) called (even today by the natives) PPa PPhol chac that is where today is built the convent of my father of San Francisco and means in Spanish the name "House of Heads and Lightning" and it is there that the priests of the gods dwelled. They were greatly venerated. They were the lords and the ones that gave punishment and reward. They were obeyed completely no matter what was said.

On the other hand the priests were called and are called today in the Maya language $A b[\mathrm{Ah}] \mathrm{Kin}$, that is derived from the verb Kinyah that means to draw lots or throw dice, and because the priests threw dice or drew lots on their sacrifices when they wanted to know something or to answer questions made of them, they 
call them Ala[?]Kin and today in their language they call the Christian priest $A b[\mathrm{~h}]$ $\mathrm{Kin}$, as they called the priest of the false gods in the ancient time.

There is another mound that was the home and dwelling place of a great captain that was called HunpictoK, and this is located between the south and the west, and the name of the captain means in Spanish "Captain that has an Army of Eight Thousand Flints that was the steel in their lances and arrows with which they fought the wars." Their work was mainly to subject the vassals and merchants that the king or priest keeps, they who defend the subject of the kingdom and the temples.

These were the oracles most named at Ytzamat ul, or Ytzamal, as they call it today. So that something may be known about the ceremonies that were used in the sacrifices and penances and fasts, I shall say something in the following chapter that the reader will admire and that in the future we might speak honorably of God and His Holy Mother (Lizana, 1893: 4-5 [translation by Charles Keortge, italics and capitalization within italicized words are in the original, paragraph divisions introduced by me for clarity]).

At least four of the five structures (today's archaeological mounds) were built to venerate gods who at one time were said to be historical figures, the "founder gods," as mentioned; "Ytzamat ul," "HunpictoK," "Kal [b] Ul" and "Kinich KaKmo." "PPa PPhol chac" was the headquarters of the priesthood where today the great yellow church, atrium, and conventos dominate Izamal's central square.

\section{Native prayers}

It is extremely rare and fortunate to have a native Maya prayer recorded and preserved from the sixteenth century. It is found in the Relación de Kanpocolche y Chochola (Relaciones, 1983, Vol. 2: 322-323) within an account of a ceremony conducted by an "Ah Kin" or "Alquin." The purpose of the ceremony was to foretell or divine the weather they were going to have, if it was going to be good or bad, and if they were going to have hunger or an abundance of sustenance or nourishment (mantenimientos).

To perform the ceremony the native priest took a bread (tortilla) prepared from cooked maize, put it in his hand, and held it up to the sky. Speaking and praying he offered it up to the idol of Itzamna and said "quit ah tepale u yumi caane yan te muyal yan ti caane," which translates "father, majesty, lord of the sky, there in the clouds, there in the sky" (my translation). Afterward, the priest makes offerings of precious stones and more, and addresses two other gods: "Ku aj tepale" and "Coleleyx kanleoxe" (Holy Majesty and Lady Kanleox).

\section{Summary}

A straightforward tabulation of occurrences provides a simple yet meaningful overview of at least one aspect of Colonial period Maya religious beliefs. From 
the principal ethnohistorical sources, a simple count of the number of times a god is mentioned provides the following list of names that occur in more than one source.

Table 1 . Gods from the ethnohistorical sources and the number of separate contexts in which they are mentioned

\begin{tabular}{|l|l|l|l|l|}
\hline Itzamna (14) & K'uk'ulkan (5) & K'u (3) & Xok (2) & Kit Bolon Tun (2) \\
\hline Chaak (9) & Ek Chuah (3) & Akantun (2) & Kimi (2) & Yax Cocah Mut (2) \\
\hline Bakab (6) & Ix K'anleox (3) & Mam (2) & Pawahtun (2) & Christian Trinity (2) \\
\hline Saki' (6) & Balam (3) & Deer (2) & Tabai (2) & \\
\hline Ix Chel (5) & Hobnil (3) & Cross (2) & Ka'an (2) & \\
\hline
\end{tabular}

The dominance of Itzamna in these sources is striking, but may be attributed to the overemphasis on sources especially knowledgeable in the Izamal region, where Itzamna was the principal tutelary and founder god. Landa, Diego Quijada, and Lizana were all well-versed in "pagan" religion of the Izamal province. If our principal sources had come from Maní, perhaps K'uk'ulkan would have prevailed.

Saki' is notable for his unexpected appearance here, unexpected because this god is not known from other sources, neither the prehispanic codices nor the Classic period monuments. He appears only in the Relaciones, but that does not minimize his significance, since he outnumbers even K'uk'ulkan in number of mentions.

Notably, there is a rather balanced mix of tutelary gods (Itzamna, Saki', and K'uk'ulkan) with the gods of thunder, lightning, rain, and wind (Chaak, Bakab, and Hobnil). It is this dichotomy, the tutelary gods vs. the gods of nature, that we might keep in mind as our survey moves into the ethnographic period.

As mentioned in the introduction, these ethnohistorical sources do not constitute a complete survey of the colonial era, but rather a shorter period, from 1560 s to 1650 s. Our survey now jumps to the post-independence period, beginning in the 1850 s.

\section{Ethnographic Sources}

This section surveys the ethnographic literature from the mid-nineteenth century through the early 1980s. Undoubtedly some minor sources have been missed, but the material includes numerous, somewhat obscure, references never before cited outside the peninsula of Yucatán. As mentioned in the introduction, numerous works have appeared since 1980 that are not included for the simple reason I have not yet compiled and analyzed them to the degree I have the pre-1980 materials. 
This review divides the results into two parts, one tabulation of deity names based on ethnographers' statements, and another gleaned directly from the shamans' prayers. The reason for dividing the two is to see if there is a distinction between what ethnographers say about Maya religion and what the internal evidence from the shamans' own prayers reveals; and if there is a distinction, what is its nature.

First is a look at ethnographers' typologies. The criterion for inclusion was that the ethnographer made a statement that such-and-such class of supernatural beings was important to the Maya then under discussion, regardless of whether those categories came from interviews, general conversation, or from transcriptions of prayers (usually the reasons behind arriving at such categories are not explained by the ethnographers). This section is arranged chronologically from most recent to farthest in the past, based on date of fieldwork (where attainable) rather than date of publication. This section on ethnographers' classifications is followed then by a close inspection of the prayers themselves.

\section{Ethnographers' typologies}

Estrada Cámara (1918: 24-26) relates three deities to whom offerings are made in waajil kool, "bread of the milpa" ceremonies: "yumil-kaax," "yumil-ik," and "yumil chaac" (lord of the forest, lord of the wind, and lord of the rain). Ch'a chaak "bring rain" ceremonies are made to "yum-chaac," which the author translates as "señor del agua" (lord of the rain) while "zaca'," a ceremonial white corn drink, is offered to "los vientos" (the winds).

In a study of a native Maya bee ceremony, Tec Poot and Bocara (1980: 12) distinguish three general classes of spirit protectors: "dueños de las lluvias, montes, o abejas" (masters of the rains, forests, or bees). In almost the same breath, the authors describe the objective of the ceremony as imploring the "dueños de las lluvias, de los vientos" (masters of the rains, of the winds) (10). As a general term for the protectors or masters, the authors report (11) that the offerings are made to the "yumtsilob" (lords).

Medina reports one overriding deity, "nohoch tat," translated to Spanish as "gran señor" (great lord) who is "padre o dueño del monte" (father or proprietor of the forest). All offerings are directed to him but prayers are also made to the winds of the four directions, which are, in the order given in her report, "lakin ik," "xikin ik," "nohol ik" and "xaman can" (east wind, west wind, south wind and north sky), showing an interesting substitution of the word "sky" for "wind" (Medina, 1975: 58-60).

In Irigoyen's (1976: 50-54) description of a ch'a cháak, there is a singular overriding deity, "dios Chac," as well as four winds, "el viento del alacrán amarillo, viento del rojo, viento del negro, viento del blanco," (yellow scorpion wind, red [scorpion?] wind, black [scorpion?] wind, white [scorpion?] wind). The general term of address for the deities is "señores" (lords). 
In the ceremony of the cave of Balankanche (Barrera Vásquez, 1970: 72), the principal beings addressed in prayer are the "yum balames" (lord balams) who reside in the cave. The prayers themselves are called prayers to the "yumtsilob" (lords).

Pacheco Cruz (1947: 105, 107) emphasized two main deities, "dios chac" and "yumil kaax" defined by him in Spanish as "dueño del monte o lugar del milpa" (proprietor of the forest or place of the milpa).

Redfield and Villa Rojas, from the first half of the twentieth century, summarized the spirit world of Chan Kom, Yucatán, and found three basic classes of deities: "balams," "chaacs," and "kuilob kaaxob" (gods of the forest). The functions and attributes of these three types are kept fairly distinct in the minds of the local Maya according to the authors (Redfield and Villa Rojas, 1934: 112-113, 134).

Villa Rojas, working alone in Quintana Roo, found basically the same three groupings among the Maya of Tusik, Señor, and X-Cacal: "balamob", "chakob", and "kuilob kaxob", all falling under the rubric "yumtsilob" (Villa Rojas, 1978: 288-294; see also 1945: 101-102).

Rosado Vega briefly mentions three principal gods: "chac," "padre de la tierra," (father of the land), and "viento del agua" (wind of the rain). "Chac" is further defined as "el grande, el manejador de las aguas de lluvia, el gran fecundador" (the great one, the manager of the rains, the great fertilizer). The author does not elaborate on the other two (Rosado Vega, 1938: 82-83).

From western Belize, then British Honduras, Thompson's ethnographic report of ceremonies provides clues to a native typology. On a mesa (ceremonial altar) for a waajil kool (agricultural ceremony of petition and thanksgiving), five bowls of saka' (ceremonial white corn drink) were arranged as offerings, four in the four corners and one in the center. The largest offering, the one in the center, was called "holche" and was for God in the singular form "quh." The other four offerings were offered to gods in the plural form, representing classes of spirit beings in the mind of the presiding $j$-meen (ritual practitioner, shaman). The four groups are given by Thompson (1930: 115) as follows: "Qanan Qaxob," "Halach winkob," "Ahbejob" and "Balam winkob." Thompson's translations for these terms are "the rain gods, meaning bountiful forests," "the captains," "those who pass before," and "the tiger men or big men".

Thomas Gann reports that the principal non-Catholic gods of the Santa Cruz Maya were the chaaks or rain gods (Gann, 1917: 418; 1918: 48), and Starr's very brief mention of Maya ceremonies mentions that the $j$-meen sings are to the "winds of the four quarters" (1908: 307).

Tozzer (1907: 154-156) gives the most systematized and strictly delineated typology of all the ethnographic sources. Not only due to the various classes of deities they have distinct names and roles, they also reside in separate layers or levels of the heavens.

In the highest level, the seventh heaven, lives "El Gran Dios." In the sixth level reside the "nukuch yumchakob" (great lord rain gods) or "regadores" (waterers). Tozzer mentions that the "yumchakob" are also known as the "Astenulob", which 
translates something like "nourishers," a term not known from other sources. On the fifth level live the guardians of the milpas and the forests. The milpa guardians Tozzer records as "Qu(h)ob" and the forest guardians "A(h)kananqashob." In the fourth level reside " $\mathrm{A}(\mathrm{h}) \mathrm{kananbalcheob"} \mathrm{(guardians} \mathrm{of} \mathrm{the} \mathrm{wild} \mathrm{animals).}$ On the third level are "A(h)qaqasbalob" (devils, evil things). On the second level live four wind gods. They are "A(h)laqinqu" (east god), "A(h)chiqinqu" (west god), "A(h)noholqinqu" (south god) and "A(h)xamanqinqu" (north god). Finally, on the first level above humans, there is the home of the four "yumbalamob" (lord balams). These nocturnal beings, according to Tozzer, guard the entrances to the towns where crosses are erected on piles of stones. They protect the towns and the people in them. As indicated, the belief in levels or layers with residing spirit beings is unique in the ethnographic sources.

In a much less detailed account, Rejón García reports that during ch'a cháak ceremonies, the j-meen calls to the winds and to the rain (Rejón García, 1905: 37).

In the nineteenth century, in Brinton (1883), there are references to some apparently unpublished papers by Licentiate Zetina, a native of Tihosuco, Yucatán, in which the balams, or báalamo'ob, are discussed. "No Indian on the peninsula," according to Zetina, "neglects to propitiate the Balam with a suitable offering at the time of corn planting". The báalamo'ob are four ancient men, corresponding to the four directions, who guard the towns and protect the cornfields.

Brasseur de Bourbourg (1870: 101) reports that the Maya prayed to the sun and to the protectors of the earth (invocation au Soleil et aux dieux protecteurs des biens de la terre) to whom offerings were presented.

Finally, from the earliest source (Carrillo, 1846: 103) in the ethnographic period, comes a description of ceremonial offerings made to the "señor del campo" (lord of the fields). The offerings are similar to those found in other ceremonies described throughout the so-called ethnographic period, from mid-nineteenth century to the present. According to this source, if the Indians attempt to cut the forest to make their milpa without first making these offerings, they are putting their lives in danger. The object of this veneration is none other than "yum balam."

The types or classes of spirit beings, when compiled from the ethnographic sources cited above, fall rather neatly into the following four groupings (remembering of course the overlapping and intermingling nature of Maya deities):

Chaaks

"Yumil chaac" (Estrada Cámara, 1981: 48)

"Dueños de lluvias" (Tec Poot and Bocara, 1980: 12)

"Dios Chaac" (Irigoyen, 1976: 54)

“Chaaks" (Villa Rojas, 1945: 101-102; 1978: 288-294)

"Chaacs" (Redfield and Villa Rojas, 1934: 112, 134)

"Chac" (Rosado Vega, 1938: 83)

"Dios chac" (Pacheco Cruz, 1947: 105) 
“Chaks" (Gann, 1917: 418, 1918: 48)

“Nukuch yumchakob” (Tozzer, 1907: 155)

"La lluvia” (Rejón García, 1905: 37)

Winds

"Yumil-ik" (Estrada Cámara, 1981: 48)

"Dueños de los vientos" (Tec Poot and Bocara, 1980: 10)

"Viento del alacrán amarillo," "viento del rojo," "viento del negro,"

"viento del blanco" (Irigoyen, 1976: 50)

"Lakin-ik," "xikin-ik," "nohol-ik," “xaman-can” (Medina, 1975: 59)

"Viento de agua” (Rosado Vega, 1938: 83)

"Winds of the four corners" (Starr, 1908: 307)

"A(h)laqinqu," "A(h)chiqinqu," "A(h)noholqinqu," "A(h)xamanqinqu"

(Tozzer, 1907: 155-156)

"Los vientos (Rejón García, 1905: 37)

Forest guardians

"Yumil-kaax" (Estrada Cámara, 1981: 48)

"Dueños de los montes" (Tec Poot and Bocara, 1980: 12)

"Padre o dueño del monte" (Medina, 1975: 60)

"Yumil kaax" (Pacheco Cruz, 1947: 107)

"Kuil-kaaxs" (Villa Rojas, 1945: 101-102; 1978: 288-294)

“Kuilob kaaxob” (Redfield and Villa Rojas, 1934: 112, 134)

"Qanan Qaxob” (Thompson, 1930: 115)

Balams

"Yum balames" (Barrera Vásquez, 1970: 72)

"Balams" (Villa Rojas, 1945: 101-102; 1978: 288-294)

"Balams" (Redfield and Villa Rojas, 1934: 112, 134)

"Balam winkob" (Thompson, 1930: 115)

"Yumbalamob" (Tozzer, 1907: 156)

"Balams" (Brinton, 1883)

"Balam" (Carrillo, 1846: 103)

All the above fall within the general term yuuntsilo'ob. Yuum is a kin term in Yucatec (father) as well as a general title of respect. Regarding spirit beings or gods, it might best be translated as "lord." As can be seen from the lists above, it is often used while naming beings in the spirit world such as yuum báalam or yuum cháak. The following brief list cites ethnographers' use of yuuntsilo'ob (the $m$ in yuum often shifting to $n$ ) as an overarching term referring to deities or spirit beings in general: 
Yuntsils

"Yumtsiloob" (Tec Poot and Bocara, 1980: 11)

"Señores" (Irigoyen, 1976: 50)

"Yuntsiloob" (Barrera Vásquez, 1970: 78)

"Yuntsilob" (Redfield and Villa Rojas, 1934: 113)

"Yumtsilob" (Villa Rojas, 1945: 111; 1978: 288)

At a glance, one sees that the dominant theme crossing the boundaries of the groups is weather and agriculture, not surprising in light of the Maya corn farmer's almost total dependence on his milpa for life sustaining harvests. Gone are the tutelary or founder gods of the ethnohistoric period, leaving the chaaks, winds, guardians and balams to watch over and protect the Maya farmers, their families, and their precious planting lands.

Typologies from the prayers

Departing from what the ethnographers say about the Maya spirit world, the next section is derived solely from the shamans' prayers themselves, as transcribed and published in the various sources. While the ethnographers' categories do appear in the spoken prayers, additional and perhaps surprising new classes of beings emerge. As explained in the introduction, references to Catholic saints, the trinity, the holy cross, and so on, while pervasive in these prayers, are not included in this inventory.

\section{Yuntsils}

The use of yuuntsil in the prayers conforms to what the ethnographers have said, it is a generic term for the gods and protectors, and not a specific class or type of god (Love, 1984: 266, 290). In the Balankanche prayers they sometimes appear in groups of thirteen, "trece yuntsilo"” (Arzápalo, 1970: 83), but more often appear as simply "santo yuntsilo'." In Quintana Roo, the prayers recorded by Villa Rojas use the general term "le santo yumtsilob" (1945: 159), and from northwestern Belize, Thompson recorded "nukuch (great) yumileex" in a prayer from the Maya of Socotz (1930: 116). Finally, in the prayer that Brasseur de Bourbourg recorded, there are the phrases "u pahtabal (powerful?) uumtzilob" and "lakin uume" (east lord) (1870: 101).

Chaaks

The cháako'ob are often referred to as rains gods, but just as important, they are gods of thunder and lightning. In the prayers they may be addressed in the singular, in the plural, with specific numbers, or with specific identities or aspects. 
For examples of the singular, one finds "santo chak" (Tec Poot and Bocara, 1980: 16), "yum chaac" (Estrada Cámara, 1981: 25), "yum chaak" (Arzápalo, 1970: 88) "hun tul chaac" (Redfield and Villa Rojas, 1934: 340, 350, 351), "dios chaac" (Redfield and Villa Rojas, 1934: 340, 343), "nucte chaac" (Redfield and Villa Rojas, 1934: 346, 347, 356) and just plain "chac" (Gann, 1917: 414).

As a group of unspecified number, the Balankanche prayers address "nuestros santos chaakes" (Arzápalo, 1970: 97), but also refer specifically to thirteen cháako’ob, "trese yum chaaco" (99). By far the most consistent association found in the names of the cháako'ob is with "sky," in Mayan, ka'an. Ka'an is used so consistently with cháak over the years by so many different j-meeno'ob that the name of the being or god could be thought of as ka'an cháak, not just cháak, a pattern that also appears half a millennium earlier in the hieroglyphic codices (Love, 1994: 67-68).

From Chan Kom (Redfield and Villa Rojas, 1934) there is "hatzen-caan-chaac" (lightning-strike sky chaak) $(344,355)$, "lelen-caan-chaac" (lightning-flash sky chaak) (344, 345, 349), "yum bohol-caan-chaac (father booming? sky chaak) $(345,355)$, "ttupil-caan-chaak" (last-born sky chaak) $(345,355)$, and "xoc-tuncaan-chaac" (? ? sky chaak) (345). In the prayers recorded by Villa Rojas in Quintana Roo, there are five different ka'an cháako'ob (1945: 159): "mizencaan chaac" (sweep sky chaak), "ah thoxon caan chaac" (pour-out sky chaak), "bolon caan chaak" (nine sky chaak), "lelem caan chaak" (lightning-flash sky chaak), and "hohop caan chaak" (flaming? sky chaak).

In two cases cháak is specifically located in the east. From Chan Kom (Redfield and Villa Rojas, 1934: 351) there is "yumbil huntul chaac ti noh lakin" (father one chaak at the great east) and from Tusik, Quintana Roo (Villa Rojas, 1945: 159), "yum zastunchac ti tan lakin" (father divining-crystal chaak before the east).

Gann recorded a prayer to "yum can chaacob" (father sky chaaks) (1917: 415; 1918: 47) and going well back into the nineteenth century, from Brasseur de Bourbourg (1870: 102) there is the phrase "ahtzolan kan chac" (set-in-order sky chac).

Winds

In prayers for healing and cleansing, illness-causing winds are called by name and exorcized by praying and brushing with leaves. The list of names of winds that can cause illness is almost endless (Love, 2004: 13), but as a rule these are minor winds when compared to the winds of the four directions, winds that bring rain. It is often difficult to distinguish the two classes.

A good sample of the many and varied types of winds appears in the text of a prayer from a curing ceremony recorded and published by Pacheco Cruz in which no fewer than thirty winds are addressed by name (1934: 65, see also Love, 2004: 13), including winds of the four directions, geological formations (cenote wind, cave wind), heavens (sky wind, rain wind), and animals (cat wind, peccary wind, armadillo wind, snake wind). The animal winds are the largest group. 
Three winds in a group are addressed repeatedly in the Becanchen prayers, "k'en ke'eles ik'ob" (twist cold? winds), "t'ul pach ik'ob" (follow behind winds) and "moson ik'ob" (whirlwinds), all are associated with the milpa (Love, 1984: 291-292). In prayers from Pustunich that Arzápalo has transcribed, there is another rather extensive group of winds-many with obscure names that resist translation - that also include the winds of the four directions. In the larger ceremonies, such as agricultural ceremonies and the cave ceremony at Balankanche, mention of winds may occur as a more general reference, such as "santo ik'ob" (Tec Poot and Bocara, 1980: 19) or "e ik'e” (Arzápalo, 1970: 99).

One particular wind is named frequently enough, even in the larger ceremonies, to warrant special mention. This wind is mosoon iik', whirlwind. It is found in recorded prayers from two waajil kool performances and a ch'a cháak spanning the years from 1978 (Love, 1984) back to 1915 (Gann, 1917: 416; 1918: 47). It is also recorded from a short prayer used prior to firing a milpa, addressed as "kakal moson-ik'ob" (fiery whirlwinds) (Redfield and Villa Rojas, 1934: 339).

Kanans

Guardians or protectors are mentioned throughout the prayers from Yucatán. In the two most recently recorded instances, the term "kalan" rather than "kanan" is used but it is translated in both cases by Yucatec-speaking consultants as "guardian," the same as "kanan."

The distinguishing feature about the kanano'ob is that they are associated in almost all cases with the lands and forests, especially the rich planting lands known as ka'kab k'ax or ka'kab lu'um (Barrera Vásquez, 1980: 283) where farmers make their milpas, areas with dark soil. The guardians of these regions appear more frequently in the prayers than any other of the various kanano'ob. They are called, in various orthographies, "ah kanan kakbo" (Arzápalo, 1980: 140); "ah-canan-cacabob," "yum ah canan-cacabob" and "canan-cabob (Redfield and Villa Rojas, 1934: 344, 347, 350); "ah canan cacabob" and "canan cacbilob" (Villa Rojas, 1945: 159); and finally "in cichkelem tata ah canan kakabol" (Gann, 1918: 47).

The second most frequently mentioned kanano' $o b$ are the guardians of the forest or k'áax. These, in turn, appear as "canan kaaxilob" (Redfield and Villa Rojas, 1934: 351), "canan kax" (Villa Rojas, 1945: 159), and "le qanaan qaxobe" (Thompson, 1930: 116). The milpa itself, kool [rhymes with pole], is mentioned twice, once in the most recently recorded prayer and once from over one hundred years earlier: "kalan kolob" (Love, 1984: 266-299 passim) and "ah canan colóob [sic]" (Brasseur de Bourbourg, 1870: 102). Without listing all the other specific names of guardians, let it be said they include guardians of cenotes, mountains, knolls, marshy areas, stone mounds, milpa boundary stones, cleared zones around the milpa, seeds, and more for which translations are unsure. 
Balams

Báalamo'ob are mentioned in several prayers from the ethnographic period. Although sometimes addressed in general terms, such as "yum balamob" and "dios balam" (Redfield and Villa Rojas, 1934: 339, 349), more often the báalamo'ob have very specific aspects or roles which are included as part of their names. Three balams are grouped together in the Becanchen prayers (Love, 1984: 266-299 passim); "t'up k'ab balam," "t'ox k'ab balam” and "nohoch balam," (last-born or last-inline hand balam, pour-out hand balam, great balam). (Balam is not glossed in English here. They are not jaguars, which is the dictionary definition, but rather a class of spirit protectors, whose name does not translate well to other languages.)

Balams often appear in groups of specified number, in two recorded sets of prayers as four-part beings: "Señor yum ah kan balam" (lord father four balam) (Arzápalo, 1980: 141), and "can tul nucte balamob” (four great balams) (Redfield and Villa Rojas, 1934: 341, 351). In the prayers from Balankanche they appear in sets of three " "oxtun balmo" (Arzápalo, 1970: 139), four "kwatro yum mistun balam” $(110,111)$, five "ho'tun balmo" $(82,96,136,138)$, and thirteen "trese nikte balmo'" $(99,105)$ and "trese multa balmo"” (139). There is also reference to "sesenta y sinko (66) batan balmo"” (150).

Many of the báalamo'ob from the Balankanche prayers have names which are not translated by the authors, nor are they readily identifiable by using the Maya dictionaries; names such as "'akan balam," "'okon balmo" and "'ahab balmo." "Balam kanhel" is interesting because of the debate on whether the term "kanhel" comes from the Spanish "angel” or has precolumbian origins (see Roys, 1933: 67).

Noj k’ab

Noj $k^{\prime} a b$, the great hand or right hand is tentatively identified here as an object of veneration, a poorly understood and little recognized aspect of native Maya ritual that rather consistently surfaces in ceremonial prayers, but is yet to be ranked with the chaaks or balams. It appears as an object of reverence, the receiver of offerings, or one of the entities to which prayers are addressed. (All but one of the following examples has been previously published [Love, 1988] but they, along with the one additional example, are repeated here to facilitate the reader's access to the material.) During prayers for a ritual cleansing near Ticul, William Hanks recorded the lines "aweensik ten akichkelem no ak'ab yook'ol le kweerpo" (you lower for me your beautiful right hand over the body [Hanks' translation]) (Love, 1984: 160). At the end of the waajil kool ceremony at Becanchen, the milpero approaches the mesa and, repeating after the j-meen, offers his pledge (promesa) to the great right hand in exchange for protection (Love, 1984: 300).

In the bee ceremony recorded by Tec Poot and Bocara, offerings are made and prayers are addressed to the right hand or great hand of "hahal dios" (true god), "santo Cristo" (holy Christ), and "koolebil Maria” (lady Mary) (1980: 13-15). In the 
prayers from the Cave of Balankanche, "noh kris noh u k'a"' (great Christ, great his hand) is repeatedly addressed (Arzápalo, 1970: 82, 98). Villa Rojas records "Tin kubic ti noh a kabex le zuhuy trece-uah..." (I am delivering to your great right hand the thirteen-layered bread...) (1945: 160; 1987: 458).

Lest one think the right hand refers only to Christ and the trinity, in Chan Kom, besides "u kab Dios" there is also reference to "noh u kab nucte chaak, noh kab nucte balam" (right hand of the great chaak, right hand of the great balam) (Redfield and Villa Rojas, 1934: 345). Finally, from the nineteenth century, the Christian trinity appears again with "utial k'ubik ti u kab dios yumbil, dios mehenbil, dios expiritu santo" (in order to deliver it to the hand of lord God, God the son, and God the holy spirit) (Brasseur de Bourbourg, 1870: 101-102).

Tepals

Surprisingly, one consistently mentioned title or group name that appears in the prayers has received almost no discussion by Yucatec Maya ethnographers. The term is tepal and translates ruler or sovereign. In the Becanchen prayers, the tepalo'ob appear with two other groups of beings, the "workers" and the "waterers," so together their names are rapidly repeated in the prayers as "ah meyahob, ah hoya'ob, ah tepalob xan" (Love, 1984: 292).

From Tusik, Quintana Roo, these spirit beings are asked to receive offerings and are addressed as "noh Ah-tepalob" and "le noh tepalob" (Villa Rojas, 1945: 160; 1978: 458). In the Chan Kom prayers they appear alongside the guardians of the milpa lands, so in one prayer, for instance, ceremonial breads are offered to "yum ahcanan-cacabob, ti ahtepalob" (Redfield and Villa Rojas, 1934: 347-348).

In the ch'a cháak ceremony recorded by Gann, the $j$-meen addressed the "atepalob" during a very short prayer when placing the ceremonial breads in the earth oven, and again, in a longer prayer, after the mesa was arranged with offerings and the main part of the ceremony was performed (Gann, 1917: 414, 416; 1918: 46, 47).

The term appears also in Brasseur de Bourbourg (1870: 102) where it shows a very close and therefore interesting parallel with the prayer Gann recorded some four and a half decades later. In both prayers, the tepalo'ob are associated with chúumuk ka'an, the zenith. In the Gann prayer, the phrase "atepalo chumuc caan" is used (1917: 415; 1918: 47). In the Brasseur de Bourbourg prayer there is "chumuc ti canil ahtepal" (1870: 102), clear evidence that to at least some Maya ritual practitioners the tepalo'ob are related to the zenith.

Pawahtuns

Pawahtuns show up twice in the transcripts of the prayers from the ethnographic period. In both cases they are quadripartite in nature, with four different colors associated with their names: in Chan Kom, "ek pahuatun," "chac pahuatun," "kan pahuatun" and "zac pahuatun" (black, red, yellow and white) (Redfield and Villa 
Rojas, 1934: 354-355); in Quintana Roo, "Yaxpapatun," "Chacpapatun," "Kanpapatun" and "Ekpapatun" (blue-green, red, yellow, and black). That "papatun" is a modern corruption of the more ancient "pawahtun" is suggested by Barrera Vásquez (1976: 38-41).

K'u

$K^{\prime} u$ as a term for god finds expression occasionally in the ethnographic material. Redfield and Villa Rojas' "kuil kaax" (see Forest Guardians, above) translates something like "god of the forest." The j-meen at Chan Kom also makes reference to "yax mesa kuh" (blue-green or fresh mesa of god) (Redfield and Villa Rojas, 1934: 345), and before the hunt to procure animals for a ch'a cháak feast, prayers were made to "ah ku kaax," (god of the forest). Pacheco Cruz gives a brief prayer for rain addressed to "Ku" (1947: 103) and Eric Thompson, from Belize, recorded prayers to "yum quhoba" (1930: 116).

Joyas

The jóoya'o'ob are waterers or sprinklers, based on the root word jóoy (pour out liquid). Perhaps they are cognate with chaaks and represent only linguistic substitution, but they do receive their own attention in prayers from Becanchen, "hoya'ob" (Love, 1984); Balankanche, "yum ah hoya" (Arzápalo, 1970: 125, 140); and Chan Kom, "ah hoyabilob," "hoyah semilla" and "hoya semillaob" (Redfield and Villa Rojas, 1934: 351, 344, 346), the latter two apparently waterers of seeds.

X-Kanleox

Kolel (Lady) X-Kanleox is an important female deity who has survived over the post-contact centuries to appear still today in the modern shamans' prayers. To translate her name, Gann breaks it down to its constituent parts; k'aan-yellow, le'-leaf, and óox-ramon tree (1917: 415; 1918: 47). Villa Rojas calls her the yellow goddess (1945: 159) and equivalent to the Catholic Church's Mary Magdalena; but this is contradicted by internal evidence from the prayers that Villa Rojas recorded, in which the $j$-meen calls to four ki'ichkelem ko'olelo'ob (beautiful ladies) in succession, Guadalupe, Verónica, Magdalena and Kanleox, so it seems unlikely that Magdalena and Kanleox are one and the same.

Barrera Vásquez argues rather convincingly that "Kolel X-Kanleox" may be the original ancient Maya goddess of maize (1981), an idea made even more interesting because two maize protectors in the prayers from Chan Kom are also female, "cichpan colel canan gracia" (beautiful lady protector of maize) and "cichpan colel metaan gracia" (beautiful lady? maize) (Redfield and Villa Rojas, 1934: 345). 


\section{Aj K'in}

The sun itself is mentioned as a deity or spirit being in prayers from two separate sources: in the bee ceremony recorded by Tec Poot and Bocara, "ah k'ini" and "señor santo k'in" (1980: 17, 18); and from Pustunich, "santo espiritu ti k'in" (Arzápalo, 1980: 145).

\section{Aj Bej}

The spirits of the road or those that travel the road are referred to as "santo espíritus ti beh" in the Pustunich prayers (Arzápalo, 1980: 145) and "ahbehobe" in the Socotz prayers from the 1920s recorded by Thompson (1930: 116).

\section{Miscellaneous}

Several spirit beings appear only once in this collection of transcribed prayers. They are tabulated here:

\begin{tabular}{|c|c|}
\hline Love, 1984 & $\begin{array}{l}\text { "hil p'isib che'" (he who measures the forest), "meyahob" (workers), "nukuch ak'ab } \\
\text { xuxubobo" (great night whistlers), "yum kuch" (lord burden bearer). }\end{array}$ \\
\hline $\begin{array}{l}\text { Tec Poot and } \\
\text { Bocara, } 1980\end{array}$ & "Kichpan santo mama luna" (beautiful holy mother moon). \\
\hline Arzápalo, 1980 & $\begin{array}{l}\text { "mama xunan" (mother lady), "señor yum ah itsa" (sir lord ah itsa), "señor yum } \\
\text { bitsini" (sir lord ?), "yum ah ka' mul" (lord twin mounds) }\end{array}$ \\
\hline Arzápalo, 1970 & $\begin{array}{l}\text { "santo sayab" (holy cenotes/springs), "santo trono" (holy thunder), "santo chi" } \\
\text { (holy mouth of cenote), "santo ha"' (holy rain), "santo personas" (holy beings), } \\
\text { "chan alux" (small forest goblin), "noh alux" (great forest goblin) }\end{array}$ \\
\hline $\begin{array}{l}\text { Redfield and } \\
\text { Villa Rojas, } 1934\end{array}$ & $\begin{array}{l}\text { "yum ziz cunah-era" (lord mediator? cornfield), "ek zipilob" (black deer guardians), } \\
\text { "ppaap zipob" (? dear guardians), "suhuy alak" (virgin companion), "noh yum cab" } \\
\text { (great lord of the bees), "x-mulzen cab" (lady ? bees), "bolon hobon" (nine bee- } \\
\text { hive), "bolon hac matz" (nine?) }\end{array}$ \\
\hline Thompson, 1930 & "nukil winkob," "halach winkobo" (great men, principal men) \\
\hline Gann 1917, 1918 & $\begin{array}{l}\text { "yum kankin" (lord ?), "cichkelem tata Cakaal Uxmal" (beautiful father planting } \\
\text { lands of Uxmal), "cichkelem tata yum xualakinik" (beautiful father lord ?) }\end{array}$ \\
\hline $\begin{array}{l}\text { Brasseur de } \\
\text { Bourbourg, } 1870\end{array}$ & "u lahbalob" (?), "u tzolan kancheob" (arranged-in-order gardens?) \\
\hline
\end{tabular}

Table 2. Miscellaneous spirit beings mentioned in shamans' prayers

\section{Summary}

For the gods mentioned two or more times in the prayers, if one counts the number of separate sources in which they appear, a rough hierarchy emerges. 


\begin{tabular}{|l|l|l|l|l|l|l|}
\hline Chaaks (8) & Kanans (6) & Winds (6) & Yuntsils (5) & Balams (5) & Noj K'ab (5) & Tepals (5) \\
\hline K'u (3) & X-Kanleox (3) & Joya (3) & Pawajtuns (2) & Aj K'in (2) & Aj Bej (2) & \\
\hline
\end{tabular}

Table 3. Gods from the ethnographic prayers and the number of separate sources in which they appear

The first five categories neatly match the ethnographers' classifications, reassuring us that the ethnographers got it right, but then come noj k'ab, the great right hand, and the tepals, translating something like rulers or sovereign ones. Noj k'ab, it has been suggested, might survive from prehispanic times when it appears on ceremonial staffs in Maya codices and when a great statue of a hand was said to have had miraculous powers at Izamal (see Lizana, above) where pilgrims came from the four corners of the world to leave offerings in exchange for healing (Love, 1988). However, it could just as well reflect the Catholic notion of the right hand of God, or for that matter the Muslim healing hand introduced from Moorish Spain.

The tepalo'ob are mentioned not at all in the ethnohistorical sources reviewed here, nor in the ethnographers' statements about Maya deities. Only by parsing the recorded prayers do they appear. They do, however, make multiple appearances in the Chilam Balam books (sources not included in the current survey [see Bricker 1990a, 1990b for useful morpheme concordances]), pointing to remarkable continuity over several centuries, a continuity that might have gone unnoticed if the prayers themselves had not been inspected. ${ }^{2}$

The preceding data span a long period, from mid-nineteenth century to late twentieth. Are there changes that can be detected over time? Apparently not, at least from this limited set. Of the five most frequently mentioned categories, all span the entire period.

\section{Conclusion}

One of the key points that Nicholson made for Aztec religion holds true for the post-contact Maya, in spades.

No deity enjoyed a more active or widespread cult than the ancient supernatural believed to control the indispensable crop-fertilizing rain. Tlaloc was the deity most clearly conceived in quadruple and quintuple form, each Tloloque assigned, with his distinctive color, to one of the four cardinal directions (Nicholson, 1971: 414).

\footnotetext{
${ }^{2}$ It should probably be mentioned that within all the native prayers collected for this survey, not once is there mention of layers or levels of heaven or the underworld. There are multiplicities of form, four and thirteen-part manifestations of chaak for instance, but not in the hierarchical sense of levels, one above the other. Neither do such levels appear in the ethnohistorical sources, at least the small sample reviewed here. Students of Maya cosmology should be very careful about accepting the existence of such levels uncritically.
} 
Substitute Chaak for Tlaloc and one of the principal findings of this report is summarized. The one constant within the three sets of data-ethnohistorical sources, ethnographers' typologies, and typologies from the prayers-is the importance of the chaaks to the Maya of Yucatán. Without rain there is no corn, and without corn there is no life.

By the mid-nineteenth century the founder gods of the Maya cities-Itzamna, Saki' and K'ul'ulkan - had disappeared from the Maya Universe while gods of the sky and forest remained. I suspect the founder gods were more vulnerable to Colonial period disruption. They were physically more prominent-often set as statues or idols on tops of the highest pyramids - which made them obvious targets for Church "reform". As tutelary gods, abogados of polities and social units, the Colonial destruction of such units by depopulation and resettlement would render them impotent. Gods of rains and winds, however, never became obsolete; and Maya farmers today continue to maintain their all-important partnership with these invisible forces.

\section{REFERENCES}

Anders, Ferdinand

1963 Das Pantheon der Maya. Graz, Austria: Akademische Druk.

Arzápalo, Ramón

1970 "The Ceremony of Tsikul T'an Ti' Yunstiloob at Balankanche: Transcription and Translation of the Maya Text”, Balankanche, Throne of the Jaguar Priest, pp. 79-164, E. Wyllys Andrews IV (ed.). New Orleans: Tulane University (MARI Publication, 32).

1980 "Contribución para el estudio de la religión maya a través de textos religiosos modernos”, Indiana, 6: 137-153. Berlin: Gedenkschrift Walter Lehmann, Gebr. Mann Verlag.

Barrera Vásquez, Alfredo

1970 "The Ceremony of Tsikul T'an Ti' Yunstiloob at Balankanche: Description of the Ceremony", Balankanche, Throne of the Jaguar Priest, pp. 72-78, E. Wyllys Andrews IV (ed.). New Orleans: Tulane University (MARI Publication, 32).

1976 El Folk-Lore de Yucatán. Spanish translation of Brinton, 1883 with notes. Mérida: Ediciones del Gobierno del Estado. Talleres Gráficos y Editorial Zamna. [Originally published 1937, Museo Arqueología de Yucatán, Pub. 3, Mérida.]

1980 Diccionario Maya Cordemex, Maya-Español, Español-Maya. Mexico: Cordemex.

1981 “La Identificación de la Deidad 'E’ de Schellhas. Reprinted”, Estudios Lingüísticos, Alfredo Barrera Vásquez, Obras Completas, Vol. 2, pp. 57-71. Mérida: Fondo Editorial de Yucatán. [Originally published 1939 (publisher unknown), Mérida.]

Barrera Vásquez, Alfredo, and Sylvia Rendón

1948 El Libro de los libros de Chilam Balam. Mexico: Fondo de Cultura Económica. 
Brasseur de Bourbourg, Charles Etienne

1870 Manuscrit Troano: Etudes sur le Systéme Graphique et la Langue des Mayas, Vol. 2. Paris: Imprimerie Impériale.

Bricker, Victoria R.

1990a A Morpheme Concordance of the Book of Chilam Balam of Tizimin. New Orleans: Tulane University (MARI Publication, 58).

1990b A Morpheme Concordance of the Book of Chilam Balam of Chumayel. New Orleans: Tulane University (MARI Publication, 59).

Brinton, Daniel Garrison

1883 "The Folk-lore [sic] of Yucatan”, The Folk-lore Journal, 1: 244-256. London: The Folklore Society.

Carrillo, Estanislao

1846 "Fantasmas: Papeles Sueltos del P. Carrillo", Registro Yucateco, 4: 103-106. Mérida: Castillo y Compañía.

Cogolludo, Diego Lopez

1954 Historia de Yucatán. 4th ed. Campeche: Talleres Gráficos del Gobierno.

Estrada Cámara, Rubén

1981 Ceremonias y Leyendas Mayas. 2nd ed. Mérida: Fondo Editorial de Yucatán/ PESIP, Arte y Comunicación.

Gann, Thomas W. F.

1917 "The Chachac, or Rain Ceremony, as Practiced by the Maya of Southern Yucatan and Northern British Honduras", Proceedings of the Nineteenth International Congress of Americanists, pp. 409-419; F. W. Hodge (ed.). Washington, D. C.: Smithsonian Institution Bureau of American Ethnology.

1918 The Maya Indians of Southern Yucatan and Northern British Honduras. Washington, D. C.: Government Printing Office (Smithsonian Institution Bureau of American Ethnology Bulletin, 64).

Gibson, Charles, and John B. Glass

1975 "A Census of Middle American Prose Manuscripts in the Native Historical Tradition", Guide to Ethnohistorical Sources Part Four, pp. 322-400, H. F. Cline (ed.). Austin: University of Texas Press (Handbook of Middle American Indians, 15).

Hanks, William F.

1984 "Sanctification, Structure, and Experience in a Yucatec Ritual Event", Journal of American Folklore, 97 (384): 131-166. New York: American Folklore Society.

Irigoyen, Renan

1976 Esencia del Folklore de Yucatan. 2nd ed. Mérida: Ediciones del Gobierno del Estado. 
Kelley, David H.

1976 Deciphering the Maya Script. Austin: University of Texas Press.

Landa, Diego de

1941 Landa's Relación de las Cosas de Yucatán. Translated and edited with notes by Alfred M. Tozzer. Cambridge, Massachusetts: The Museum (Papers of the Peabody Museum of American Archaeology and Ethnology, 18). [Written 16th century.]

Lizana, Fray Bernardo

1893 Historia de Yucatan: Devocionario de Ntra. Sra. de Izmal [sic] y Conquista Espiritual. Reprinted. Mexico: Museo Nacional de México. [Originally published 1633, Valladolid, Spain.]

Love, Bruce

2004 Maya Shamanism Today: Connecting with the Cosmos in Rural Yucatán. Lancaster, California: Labyrinthos Press.

Love, Bruce

1984 "Wahil Kol: A Yucatec Maya Agricultural Ceremony”, Estudios de Cultura Maya, 15: 251-300. Mexico: Universidad Nacional Autónoma de México.

1988 "The Human Hand as Power Object in Yucatec Ritual”, Journal of Mayan Linguistics, 6: 103-113. Los Angeles: Baton Rouge.

1994 The Paris Codex: Handbook for a Maya Priest. Austin: University of Texas Press.

Marcus, Joyce

1978 "Archaeology and Religion: A Comparison of the Zapotec and Maya", World Archaeology, 10 (2): 172-191. United Kingdom: Routledge.

Medina E., Elsie

$1975 \quad$ El alma de Campeche en la leyenda maya. Reprinted. Originally published 1948. Campeche: Departamento de Difusión Cultural, Secretaría de Educación Pública (Serie Cuadernos Informativos, Universidad del Sudeste).

Nicholson, Henry B.

1971 "Religion in Pre-Hispanic Central Mexico", Archaeology of Northern Mesoamerica, Part One, pp. 395-446, G. Ekholm and I. Bernal (eds.). Austin: University of Texas Press (Handbook of Middle American Indians, 10).

Pacheco Cruz, Santiago

1934 Estudio Etnográfico de los Maya del ex Territorio Quintana Roo. Mérida: Imprenta Oriente.

1947 Usos, costumbres, religión i supersticiones de los mayas. Mérida: Imprenta del Sr. Enrique G. Triay.

Redfield, Robert, and Alfonso Villa Rojas

1934 Chan Kom, A Maya Village. Washington, D. C.: Carnegie Institution of Washington (Publication 448). 
Rejón García, Manuel

1905 Supersticiones y leyendas mayas. Mérida: Imprenta La Revista de Mérida

Relaciones Histórico-Geográficas de la Gobernación de Yucatán.

1983 Edited by Mercedes de la Garza et al.; paleography by María del Carmen León Cázares. Mexico: Universidad Nacional Autónoma de México (Fuentes para el Estudio de la Cultura Maya, 1), 2 vols.

Rosado Vega, Luis

1938 Amerindmaya. Mexico: Botas.

Roys, Ralph L.

1933 The Book of Chilam Balam of Chumayel. Washington, D. C.: Carnegie Institution of Washington (Publication 438).

1965 Ritual of the Bacabs, a Book of Maya Incantations. Norman: University of Oklahoma Press.

Scholes, France V., and Eleanor B. Adams

1938 Don Diego Quijada: Alcalde Mayor de Yucatan, 1561-1565. México: Porrúa e hijos (Biblioteca Histórica Mexicana de Obras Inéditas, Vols. 14 and 15), 2 vols.

Starr, Frederick

1908 In Indian Mexico: a Narrative of Travel and Labor. Chicago: Forbes and Company.

Taube, Karl A.

1992 The Major Gods of Ancient Yucatan. Washington, D. C.: Dumbarton Oaks Research Library and Collection (Studies in Pre-Columbian Art and Archaeology, 32).

Tec Poot, José, and Michel Bocara

1980 "Abejas y hombres de la tierra maya”. Boletín de la Escuela de Ciencias Antropológicas de la Universidad de Yucatán, 7 (42): 2-24. Mexico: Escuela de Ciencias Antropológicas de la Universidad de Yucatán.

Thompson, J. Eric S.

1930 Ethnology of the Mayas of Southern and Central British Honduras. Chicago: Field Museum Press (Field Museum of Natural History, 274; Anthropological Series 17,2$)$.

1966 The Rise and Fall of Maya Civilization. Norman: University of Oklahoma Press.

1970 Maya History and Religion. Norman: University of Oklahoma Press.

Tozzer, Alfred M.

1907 A Comparative Study of the Maya and Lacandones. New York: The Macmillan Company. 
Villa Rojas, Alfonso

1945 The Maya of East Central Quintana Roo. Washington, D. C.: Carnegie Institution of Washington (Publication 559).

1978 Los elegidos de dios: Etnografía de los mayas de Quintana Roo. Mexico: Instituto Nacional Indigenista (Colección de Antropología Social, 56). 